\title{
Detection of Escherichia coli from the udder of the dairy farm buffaloes in Phagwara region, Punjab, India
}

\author{
Rajdeep Palaha ${ }^{1}$, Narendra Chaudhary ${ }^{2}$, Harsh Kumar ${ }^{2}$ \\ 1. Department of Health, Civil Hospital, Sangrur- 148001, Punjab, India \\ 2. Department of Biotechnology, Lovely Professional University, Phagwara- 144402, Punjab, India. \\ Corresponding author: Harsh Kumar, e-mail: harsh.12054@lpu.co.in \\ Received: 29-01-2012, Accepted: 02-03-2012, Published Online: 10-06-2012 \\ doi: $10.5455 /$ vetworld.2012.522-525
}

\begin{abstract}
Aim: To know the presence of Escherichia coli on the udder skin of the dairy farm buffaloes in the Phagwara region, Punjab, India.

Materials and Methods: A total of 135 swabbed samples were collected randomly from the udder of buffaloes in ten dairy farms over the period of three months from August to October 2011 without concern to their breed with the prior approval of the farm owners. The sterilized cotton swabs were examined by Gram's staining for the morphology of the culture, culture characteristics was confirmed by growth on different media and by preforming the different biochemical tests like Indole production, Voges- Proskauer test, Urease Production, Nitrate Reduction, Methyl red and Presumptive test.

Results: Out of 135 samples were examined, 23(17.03\%) were positive for E. coli. Most Probable Number (MPN) results confirmed the one possibility of the bacteria from the contaminated water.

Conclusion: The results of the present study suggest that $E$. coli isolates are present on the udder skin of the dairy farm buffaloes in the Phagwara region, pose a serious threat to the animal as well as consumer health. Thus, more hygienic preventive measures are required to inhibit the bacterial growth, so as to improve the health of the animals as well as the wholesomeness of the milk.

Key words: Buffaloes, Escherichia coli, Milk, Mastitis, Phagwara, Udder.
\end{abstract}

\section{To cite thisarticle:}

Palaha R, Chaudhary N, Kumar H (2012) Detection of Escherichia coli from the udder of the dairy farm buffaloes in Phagwara region, Punjab, India, Vet World, 5(9): 522-525, doi: 10.5455/vetworld.2012.522-525

\section{I ntroduction}

Escherichia coli is one of the most intensively studied living species. Escherichia coli is a normal part of the microbiota of the lower gastrointestinal tract of mammals, including humans, and usually exist as a harmless commensal. However, there also exist many pathogenic strains of $E$. coli that can cause a variety of diseases in both humans and animals [1] The mastitis which is caused by E. coli is commonly called Environmental mastitis [2]. This pathogen infects the udder generally through the ducts papillaris, which is the only opening of the udder to the outside world. In the buffalo species, mastitis is the most costly disease even though buffaloes have been traditionally considered less susceptible to mastitis than cattle [3].

However, in comparison with cattle, buffaloes have some characteristics that may contribute to greater risk to mastitis such as more pendulous udder and longer teats [4]. Higher incidence of E. coli mastitis may be due to poor hygienic conditions or intensive use of antimicrobials targeted against Gram positives for mastitis control [5]. Mastitis, inflammation of udder, results in Rs 7,165 crore annual losses to the dairy industry in India and Rs 503 crore in Punjab [6]. The percentage distribution of Gram-negative bacteria causing clinical mastitis is herd dependent, but studies in the United States and Europe consistently report that approximately $40 \%$ of clinical cases are the result of Gram-negative bacteria [7-10].

In terms of milk contamination, the quality of milk is determined by aspects of composition and hygiene. Due to its complex biochemical composition and high water activity milk serve as an excellent culture medium for the growth and multiplication of many kinds of microorganisms [11]. Among all microorganisms $E$. coli is frequently contaminating organism and is reliable indicator of fecal pollution generally in insanitary conditions of milk [12]. Two 
Table- 1. Culture Characteristics of Escherichia coli on different media

\begin{tabular}{ll}
\hline Media Used & Culture Character \\
\hline Eosin Methylene Blue Agar & $\begin{array}{l}\text { Blue- Black colonies with green metallic sheen } \\
\text { growth } \\
\text { Green metallic sheen colonies with deep pink } \\
\text { growth } \\
\text { Colourless and Yellowish white, circular, smooth } \\
\text { colonies with entire edge }\end{array}$ \\
Nutrient Agar & $\begin{array}{l}\text { Grayish Uniform turbidity having no Pellicle } \\
\text { Opaque, moist, grayish white, entire colonies }\end{array}$ \\
Nutrient Broth & Gelatin Agar
\end{tabular}

cases of hemolytic uraemic syndrome have been reported which provide evidence that raw milk may be a vehicle of transmission of $E$. coli $\mathrm{O} 157$ : H7, both affected person consumed raw milk [13]. Recovery of E. coli from food is an indicative of possible presence of enteropathogenic and/or toxigenic micro-organism which could constitute a public health hazard. Enteropathogenic E. coli (EEC) can cause severe diarrhea and vomiting in infants and young children [14].

In raw milk samples $9,20 \%$, isolates of the $E$. coli were detected, whereas in case of mastitis infected buffaloes raw milk $30.12 \%$ isolates of the $E$. coli were detected $[12,15,16]$. The detection of $E$. coli from the udder indicates a possible contamination of the surroundings like fecal matter in the soil, contaminated milking equipment's, water uses for the washing of the udder during milking. So by keeping these views in mind a study was carried out to detect the $E$. coli from the udder of the dairy farm buffaloes in the Phagwara region, Punjab, India.

\section{Materials and Methods}

Collection of sample: A total of 135 swabbed samples were collected randomly from the udder of buffaloes in ten dairy farms over the period of three months from August to October 2011 without concern to their breed with the prior approval of the farm owners. The entire swab samples were collected as per the guidelines of the International Animal Ethics Committee. Animals were not used in this experiment in anyway either experimental animals or control. The sterilized cotton swabs were swabbed onto the overall outer skin surface area of the udder. Simultaneously $100 \mathrm{ml}$ water sample were also collected for the same dairy farms to check the MPN level (most probable number). The samples were collected in the sterile sampling bottles that were kept in a cold box and were immediately shifted to the laboratory of Microbiology, Department of Biotechnology, Lovely Professional University, India.

Isolation and identification of the Escherichia coli: Each sample was inoculated on the Eosin
Table-2. Biochemical reactions of Escherichia coli

\begin{tabular}{lll}
\hline No. of Isolates & Biochemical Test & Reaction \\
\hline 23 & Catalase Test & $+\mathrm{ve}$ \\
& Simmons Citrate & $-\mathrm{ve}$ \\
Indole Production & $+\mathrm{ve}$ \\
Methyl Red & $+\mathrm{ve}$ \\
Voges- Proskauer & $-\mathrm{ve}$ \\
& Starch Test & $-\mathrm{ve}$ \\
& Urease & $-\mathrm{ve}$ \\
& Presumptive Test & $+\mathrm{ve}$ \\
& Nitrate Reduction & $+\mathrm{ve}$ \\
\hline
\end{tabular}

Methylene Blue Agar (CDH Pvt. LTD.) and incubated at $37^{\circ} \mathrm{C}$ for $24 \mathrm{hrs}$. The plates were observed for the growth of $E$. coli. A single Colony was picked and sub cultured on Eosin Methylene Blue Agar for the purification of the isolate. Gram's staining technique was used for the study of the morphology of the isolates. The culture characteristics were confirmed by inoculating the pure colonies on Endo DEV Agar (Titan Biotech LTD.), Nutrient Agar (CDH Pvt. LTD), Gelatin Agar (Titan Biotech LTD.) and Nutrient Broth (Titan Biotech LTD. Biochemical tests were performed to confirm the E. coli using Catalase test, Simmons Citrate Agar (Titan Biotech LTD.), Starch Agar (Titan Biotech LTD.), Indole production, VogesProskauer test, Urease Production, Nitrate Reduction, Methyl red and Presumptive test [17, 18].

\section{Results}

The presence of the $E$. coli on the skin of the udder was confirmed by the growth pattern on different media and by the biochemical tests whose result were given in the tables 1 and 2 respectively.

The results of the Most Probable Number (MPN) showed in table-3, which shows the level of contamination in per hundred milliliters of water sample collected from the dairy farms [19]. The water was used for drinking and washing of buffaloes udder, cleaning the utensils (used for the storage of milk) was same, hence there is always probability of contamination of E. coli, was very high, which was already there in the water, which ultimately reached the skin of the udder and utensils through water. This activity brought the bacteria directly into the milk and made it unfit for human consumption. The results of the present study were summarized in the table-4. According to these results the 23 samples out of 135 showed the presence of E. coli (17.03\%), although the percentage was less, but normal flora of the udder restricts the growth of E. coli on the udder skin [20].

\section{Discussion}

Escherichia coli is significant from the point of 
Detection of Escherichia coli from the udder of the dairy farm buffaloes in Phagwara region, Punjab, India

\begin{tabular}{ccc}
\multicolumn{2}{c}{ Table-3. MPN Results of the Water Samples } \\
\hline Serial No. & Sample Name & MPN*/ 100ml \\
\hline 1 & DF1 & 49 \\
2 & DF2 & 63 \\
3 & DF3 & 1600 \\
4 & Df4 & 4 \\
5 & Df5 & 2 \\
6 & DF6 & 13 \\
7 & DF7 & $<2$ \\
8 & Df8 & 6 \\
9 & DF9 & $<2$ \\
10 & DF10 & 14 \\
\hline
\end{tabular}

* - with $95 \%$ confidence limit

Table-4. Occurrence of Escherichia coli growth obtained from the udder

\begin{tabular}{llcc}
\hline Animal Species & $\begin{array}{l}\text { No. of samples } \\
\text { cultured }\end{array}$ & $\begin{array}{l}\text { No. of positive } \\
\text { that yielded } \\
\text { bacterial } \\
\text { growth }\end{array}$ & $\begin{array}{l}\text { \% of positive } \\
\text { samples }\end{array}$ \\
\hline Buffaloes & 135 & 23 & 17.03 \\
\hline
\end{tabular}

view of public as well as animal health, as they have been responsible for diarrheal disease in human and environmental mastitis disease in buffaloes [21,22]. There are about twelve strains associated with the bovine mastitis and five pathotypes are recognized for diarrheal in man [21,23]. As the E. coli do not normally live on the skin or in the udder but which enter the teat canal when the buffaloes comes in contact with a contaminated environment, contagious mastitis is transmitted from buffalo- cow to cow by pathogen for which the udder is the primary reservoir; it tends to be sub- clinical in nature [2]. Subclinical mastitis was found more important in India (varying from 10-50\% in cows and 5-20\% in buffaloes) than clinical mastitis (1-10\%) [24]. Common contagious pathogens have been reported to infect 7 to $40 \%$ of all buffaloes- cow [25]. Frequency of contagious pathogens among mastitis cases is greater [26].

In Faisalabad, 200 milk samples were collected from mastitis quarters of buffaloes in which the rate of contamination of the E. coli was $(1.40 \%)$, whereas 2400 milk samples were collected for screening of the sub- clinical mastitis form the six hundred lactating diary buffaloes from the four districts (Lahore, Sialkot, Narowal and Okara) in Pakistan, in which the percentage of $E$. coli was $(16.18 \%)$ [27,28]. In Jharkhand, India, $(8.95 \%)$ isolates of the E. coli were detected from the raw milk of clinical cases of the bovine mastitis [29]. Whereas $43.8 \%$ cases of $E$. coli mastitis were detected in dairy farm buffaloes in Alexandria Desert road, Egypt, as the organism were present in high level in the water tank as they act as primary reservoir for this environmental pathogen [30, 31]. Environmental factors such as poor hygiene, poor husbandry, and poor milking technique results the environmental mastitis as well as milk contamination $[4,32]$. Due to rapid urbanization, dairy animals are kept in closed areas within the boundary walls of the house and animal get with very less open and covered area. In this type of housing, overcrowding of animals results in spreading of pathogenic bacteria. The prevalence of sub- clinical mastitis was highest in

animals kept as individual holding at backyards followed by small holdings in periurban area $(42 \%)$ and the lowest at organized farms with reasonable good management conditions (32\%) [28].

While environmental mastitis cannot be totally eliminated from a herd, the incidence can be held to a minimum. The key elements in the control of mastitis include: sound husbandry practices and sanitation [33]. The result of the present study showed that $E$. coli still present on the udder skin pose a serious threat to the animal as well as consumer health. Thus, more hygienic preventive measures are required to inhibit the bacterial growth, so as to improve the health of the animals as well as the wholesomeness of the milk. Training and guidance programs should be started in order to develop awareness among farmers emphasizing the need for hygienic practice at farm level, as well as farm environment should be improved in order to decrease the breeding ground for pathogenic bacteria. Wash hands with soap and water, wash teats and udder in sanitizing solution, thoroughly dry teats and udder with individual towels, dip teats in an effective germicidal teat dip reduced the number of pathogenic bacteria from the udder skin [34].

\section{Author's contribution}

Rajdeep Palaha carried out the field study (Sample Collection), Participated in scientific discussion and sample analysis. Narendra Chaudhary participated in the sample analysis, scientific discussion. Harsh Kumar participated in the design of the study and coordination, scientific discussion and wrote the final draft. All authors read and approved the final manuscript.

\section{Acknowledgments}

Authors are pleased to thank the university authorities for providing the laboratory during this research work.

\section{Competing interest}

Authors declare that they have no conflict of interest. 


\section{References}

1. Elena, S. F., Whittam, T. S., Winkworth, C. L., Riley, M. A., Lenski, R. E. (2005). Genomic divergence of Escherichia coli strains: evidence for horizontal transfer and variation in mutation rates. International Microbiology., 8:271-278.

2. Sharif, A., Muhammad, G. (2009). Mastitis control in dairy animals. Pakistan Vet. J., 29(3): 145- 148.

3. Wanasinghe, D. D. (1985). Mastitis among buffalos in Sri Lanka. Proc. First World Buffalo Congr. Cario, Egypt. 4: 1331-1333.

4. Fagiolo, A., Lai, O. (2007). Mastitis in buffalo. Ital.J.Anim.Sc., 6: 200-206.

5. Radostits, O. M., Gay, G. C., Blood, D. C., Hinchkiliff, K. W. (2000). Veterinary medicine $9^{\text {th }}$ ed. EIBS and Bailliere Tindal, 563-618.

6. Anonymous. (2011). http://www.tribuneindia.com/ 2011/20110825/ldh1.htm.

7. Hogan, J. S., Smith, K. L., Hoblet, K. H., Schoenberger, P. S., Todhunter, D. A., Hueston, W. D., Pritchard, D. E., Bowman, G. L., Heider, L. E., Brockett, B. L., Conard, H. R. (1989). Filed survey of mastitis in low somatic cell count herds. J. Dairy Sci., 72: $1547-1556$

8. Hogan, J. S., Smith, K. L., Todhunter, D. A., Schoenberger, P. S. (1990). Bacterial count associated with recycled chopped newspaper bedding. J. Diary Sci., 73: 1756- 1761

9. Smith, K. L., Todhunter, D. A., Schoenberger, P. S. (1985). Environmental mastitis: cause, prevalence, prevention. J. Dairy Sci., 68: 1531-1553.

10. Suriyasathaporn, W., Schukken, Y. H., Nielen, M. Brand, A. (2000). Low somatic cell count: a risk factor for subsequent clinical mastitis in a dairy herd. J Dairy Sci., 83: 1248- 1255 .

11. Soomro, A. H., Arain, M. A., Khaskheli, M., Bhutto, B. (2002). Isolation of Escherichia Coli from Raw Milk and Milk Products in Relation to Public Health Sold under Market Conditions at Tandojam. Pakistan Journal of Nutrition., 1(3): 151-152.

12. Diliello, L. R. (1982). Methods in Food and Dairy Microbiology. AVI Publishing Co. Inc. Westport Connt. USA: 39

13. Martin, M., Shipman, L. D., Potter, M. E., Wachsmuth, L. K., Wells, J. G., Hedberg, K., Tauxe, R. V., Davis, J. P., Arnoldi, J., Tilleli, J. (1986). Isolation of Escherichia coli O157:H7 from dairy cattle associated with two cases of hemolytic uraemicsyndrome. Lancet. 8514- 1043.

14. Anonymous. (1975). E. coli Enteritis. Lancet, 1131-2.

15. Kumar, R., Prasad, A. (2010). Detection of E. coli and Staphylococcus in Milk and Milk Products in and around Pantnagar. Vet. World., 3 (11):495-496.

16. Iqbal, M., Khan, M. A., Daraz, B., Siddique, U. (2004). Bacteriology of mastitic milk and in vitro antibiogram of the isolates. Pakistan Vet. J., 24(4): 161-164.

17. Breed, R. S., Murray, E. G. D., Smith, N. R. (1957).
Bergey's manual of Determinative Bacteriology $7^{\text {th }}$ ed. TheWilliams and Wilkins, 336-337.

18. Cappuccino, J. G., Sherman, N. (2002). Microbiology: A Laboratory Manual $7^{\text {th }}$ ed. Dorling Kindersley, 204.

19. Cappuccino, J. G., Sherman, N. (2002). Microbiology: ALaboratory Manual $7^{\text {th }}$ ed. Dorling Kindersley, 325.

20. Woodward, W. D., Besser, T. E., Ward, A. C. S., Corbeil, L. B. (1987). In vitro growth inhibition of mastitis pathogens by bovine teat skin normal flora. Can J Vet Res., 51:27-31.

21. Anonymous. (2003). Studies on Escherichia coli. Available at: http://icmr.nic.in/annual/niced/200304/07-55-65.pdf.

22. Galiero, G. (2002). The control of environmental mastitis. Bubalus bubalis I: 26-28.

23. Kramer, T. (1961). The problems of pathogenicity of Escherichia coli in animals and man. Can. Vet. Jour., 2:326-328.

24. Joshi, S. and Gokhale, S. (2006). Status of mastits as an emerging disease in improved and periurban dairy farms in India. Ann. N Y Acad. Sci., 1081: 74-83.

25. Fox, L. k. and Gay, J. M. (1993). Contagious mastits. Vet. Clin. North Amer., 9:475-488.

26. Sori, H. A., Zerihum, A. and Abdicho, S. (2005). Dairy cattle mastits in and around sebeta, Ethiopia. Int. J. Appl.Res. Vet.Med., 3:332-338.

27. Ali, L., Muhammad, G., Arshad, M., Saqib, M. and Hassan, I. J. (2008). Bacteriology of mastitis in buffaloes in tehsil Samundri of district Faisalabad, Pakistan. Pakistan Vet. J., 28(1): 31-33.

28. Ali, M. A., Ahmad, M. D., Muhammad, K. and Anjum, A. A. (2011). Prevelance of suclinical mastits in diary buffaloes of Punjab, Pakistan. The journal of animal and plant sciences., 21(3); 477-480.

29. Ranjan, R., Gupta, M. K. and Singh, K. K. (2011). Study of bovine mastitis in different climatic conditions in Jharkhand, India. Veterinary World., 4(5): 205-208.

30. Zaki, M. M., Hesham, Y., Zorba, E. L. and Kaoud, A. H. (2010). Environemenatl organsims as risk factors in the oocurences of mastitis in dairy buffaloes with suggested methods of control. A field study. Global veterinaria., 5(2): 97- 105.

31. OZ, H. H., Hillmann, D. J. and Farnsworth, R. J. (1985). Bulk tank milk analysis for isolating mastogenic bacteria. Dairy and Food sanitation., 5: 248- 251.

32. Maniruzzaman, M., Khan, M. F. R., Amin, M. M., Paul, A. K. and Islam, M. (2010). Isolation and identifaction of bacterial flora from milk of apparently health buffalo- cows. Int. J. BioRes. 1(3): 13-16.

33. Khan, M. Z., Khan, A. (2006). Basic facts of mastitis in dairy animals: A review. Pakistan Vet. J., 26(4): 204-208

34. Jones, G. M. (2006). Understanding the basics of mastitis. Virginia Cooperative Extension, Virginia State University USA, 1-7.

$* * * * * * * *$

\begin{tabular}{llr}
\hline www.veterinaryworld.org & Veterinary World, Vol.5 No.9 September 2012 & 525
\end{tabular} 